branes usually remain uncoloured, while the ectodermal tissues, skin and retina are pigmented. It is highly probable that the rare unpigmented examples of haemochromatosis have retinae of normal aspect.

As regards the remaining features of the fundus, a little scattered irregularity of the arterial lumen was apparent in one patient. None of the other components of a diabetic retinitis were seen in these or other reported sufferers. The carbohydrate disturbance is here of a different order from that of idiopathic diabetes mellitus. The disorder is usually diagnosed at a late stage, and milder cases can readily pass unnoticed under the clinician's eyes, especially in a sunny country, so it may happen that the oculist may be able to add one more to the list of diseases first recognised through the ophthalmoscope.

I am grateful to Professor Lambie for defraying the artist's fee from funds of the Department of Medicine, University of Sydney.

\title{
THE PRIMARY POSITION OF THE EYES
}

\author{
BY \\ N. A. Stutterheim, M.D. \\ FROM THE DEPARTMENT OF FHYSIOLOGY, UNIVERSITY OF \\ THE WITWATERSRAND, JOHANNESBURG
}

THE purpose of this paper is to show that the conception of the Primary Position of the Eyes, as described in text-books, is wrong.

Duke-Elder ${ }^{1}$ states :

"When the eyes are looking straight in front, with the head vertical, with the visual axes parallel, and the vertical meridians of the two corneae both vertical and parallel, they are said to be in the PRIMARY POSITION."

Yet every thinking person must realise that when the eyes are looking-straight ahead or elsewhere-the visual axes are not parallel, but convergent. Therefore, in physiological ophthalmology it cannot be admitted that the visual axes of the looking eyes ever are parallel.

Perhaps no objection should be raised against this definition of the visual axes as parallel, if it is done arbitrarily in order to explain something. But then it is necessary that the description of the true physiological state should follow, in order to correct the wrong impression caused by so arbitrary a statement. The above textbook $^{2}$, however, goes on:

"This forms the basis of the physiological definition of the primary position of the eyes." 
It will readily be agreed that the anatomical position is the real primary position, and I shall attempt to show later what this is.

Sherrington ${ }^{3}$ writes concerning the ocular position:

"I have myself worked chiefly with the monkey. In that animal the ocular axes are parallel, and the setting of the eyeball in the orbit is such that the tensions of its connections, apart from unequal activity of its extrinsic muscles, are in equilibrium when the globes are approximately parallel. That is the primary position ... If one eyeball be then rotated by the finger or fixation forceps to right or left, or up and down, a considerable resistance is felt, and on letting it go, the globus springs back at once to the primary position. So also in chloroformisation ... So also immediately after death, before rigor mortis has set in."

Now I would like to draw attention to the fact that in man the position in ophthalmoplegia, in anaesthesia and in death, is not parallel, but divergent.

Duke-Elder's ${ }^{4}$ text-book states in this connection:

"In total ophthalmoplegia the eyes rarely look straight ahead in a parallel direction, but usually diverge slightly, and very exceptionally converge; the same orientation tends to be assumed immediately after death (v. Graefe, 1867; Grut, 1894; Oppenheim, 1905; Roelofs, 1914)."

Worth ${ }^{5}$ states concerning the position:

"In the case of a normal pair of eyes there is no such thing as static convergence ...."

Apart from the consideration of what is the actual Primary Position of the eyes, it appears to be insufficiently, realised that the anatomical position is one of stable equilibrium and perfect elasticity. It is this which causes "considerable resistance" whenever the eye is rotated away from it. The notion that the eye moves in its orbital bed, like, e.g., the caput femoris in its socket, is wrong; yet it exercises great influence on the theories of binocular and ocular motility.

\section{Investigation of the Primary Position}

I have tested the elasticity of the Primary Position. The tests were made on three baboons $(28,29$ and $30 \mathrm{lbs}$.) and on two monkeys (22 and $25 \mathrm{lbs}$.), all young healthy females.

The tests were made, first in deep general anaesthesia, and then again after death caused by the anaesthetic. Two loops of silk 00 were brought through the episcleral tissue near the limbus, one at the temporal side and one at the nasal side. By pulling on these loops the eyes could be rotated. The measurement of the tangential displacement of these rotations was taken in millimetres. The 
force needed for these displacements was recorded by a calibrated spring.

The results of the experiments were:

(1) After each displacement the eye returned to the primary position ;

(2) The force needed for each tangential displacement stood in direct and constant proportion to the degree of the displacement;

(3) After death less force was needed, but results 1 and 2 were not affected.

Conclusions :-All this can only be explained by a condition of perfect elasticity.

TEST ON MONKEY (25 lbs.)

\begin{tabular}{|c|c|c|c|c|c|}
\hline $\begin{array}{l}\text { Right Eye } \\
\text { in } \\
\text { Anaesthesia. }\end{array}$ & $\begin{array}{c}\text { Tangential } \\
\text { Displacement. } \\
\text { Millimetres. }\end{array}$ & $\begin{array}{c}\text { Force } \\
\text { in } \\
\text { Grammes. }\end{array}$ & $\begin{array}{c}\text { Right Eye } \\
\text { in } \\
\text { Death. }\end{array}$ & $\begin{array}{c}\text { Tangential } \\
\text { Displacement. } \\
\text { Millimetres. }\end{array}$ & $\begin{array}{c}\text { Force } \\
\text { in } \\
\text { Grammes. }\end{array}$ \\
\hline \multirow{4}{*}{$\begin{array}{l}\text { Movement } \\
\text { Inwards }\end{array}$} & 1 & $1 \cdot 6$ & \multirow{4}{*}{$\begin{array}{l}\text { Movement } \\
\text { Inwards }\end{array}$} & 1 & $1 \cdot 2$ \\
\hline & 2 & $3 \cdot 2$ & & 2 & 2.45 \\
\hline & 3 & 5.5 & & 3 & 4 \\
\hline & 4 & 7 & & 4 & 5.85 \\
\hline \multirow{4}{*}{$\begin{array}{l}\text { Movement } \\
\text { Outwards }\end{array}$} & 1 & $1 \cdot 65$ & \multirow{4}{*}{$\begin{array}{l}\text { Movement } \\
\text { Outwards }\end{array}$} & 1 & 165 \\
\hline & 2 & $3 \cdot 1$ & & 2 & $2 \cdot 3$ \\
\hline & 3 & $5 \cdot 1$ & & 3 & $3 \cdot 6$ \\
\hline & 4 & 8 & & 4 & 5 \\
\hline $\begin{array}{c}\text { Left Eye } \\
\text { in } \\
\text { Anaesthesia. }\end{array}$ & $\begin{array}{c}\text { Tangential } \\
\text { Displacement. } \\
\text { Millimetres. }\end{array}$ & $\begin{array}{c}\text { Force } \\
\text { in } \\
\text { Grammes. }\end{array}$ & $\begin{array}{l}\text { Left Eye } \\
\text { in } \\
\text { Death. }\end{array}$ & $\begin{array}{c}\text { Tangential } \\
\text { Displacement. } \\
\text { Millimetres. }\end{array}$ & $\begin{array}{c}\text { Force } \\
\text { in } \\
\text { Grammes. }\end{array}$ \\
\hline \multirow{4}{*}{$\begin{array}{l}\text { Movement } \\
\text { Inwards }\end{array}$} & 1 & 2 & \multirow{4}{*}{$\begin{array}{c}\text { Movement } \\
\text { Inwards }\end{array}$} & 1 & 1 \\
\hline & 2 & 3.95 & & 2 & 2 \\
\hline & 3 & 6 & & 3 & 3 \\
\hline & 4 & 8 & & 4 & 4 \\
\hline \multirow{4}{*}{$\begin{array}{l}\text { Movement } \\
\text { Outwards }\end{array}$} & 1 & 2 & \multirow{4}{*}{$\begin{array}{l}\text { Movement } \\
\text { Inwards }\end{array}$} & 1 & 0.8 \\
\hline & 2 & 4 & & 2 & $1 \cdot 8$ \\
\hline & 3 & $6 \cdot 15$ & & 3 & $2 \cdot 85$ \\
\hline & 4 & 8 & & 4 & 5 \\
\hline
\end{tabular}

The above are typical of the results obtained with all the animals tested by this method. 
This perfect elasticity is the elasticity of the anatomical structures which fix the eyeball.

Sutton ${ }^{6}$ writes:

"Many modern texts hold that the fascia bulbi forms a socket in which the globe of the eye may rotate. After a consideration of the attachments of the fascia, it is difficult to conceive of much rotation taking place.

“. . . In certain regions of the orbital septum there are to be found local thickenings of the fascia, which are known as check ligaments. Stretching, as they do, from the external surfaces of the muscles to the margin of the bony orbit, they limit to a certain degree the movements of the eyeball.

". . In an examination of the lines of reflexion of the fascia, and a consideration of the investment of the muscles as cones of fascia, it is seen that neither the muscles nor their tendons pierce the fascia bulbi.

"... Of the two check ligaments, the lateral or external is the better developed. ... There is no sharp line of demarcation between these thickenings and the adjoining parts of the orbital septum. Each becomes thinner towards the edge and finally fades out in the fascia. The predominating fibres are, according to Lockwood, elastic. Of the two ligaments, the medial contains the greater proportion of elastic fibres (Motais).

“. . The space beneath the fascia bulbi is known as space of Tenon, or the supra-scleral lymph space of Schwalbe. Extending vertically and obliquely across this space are found delicate connective tissue fibres."

The difference between these conditions and those of ordinary articulations is obvious. When its muscles are paralysed, a limb gravitates towards any position the capsule allows. When its extrinsic muscles are paralysed, the eyeball offers considerable resist-

ance to attempts at rotation, and springs back at once to the primary position when released.

And so the anatomical position of elastic slight divergence becomes the Primary Position of all binocular movements and subsequent positions.

\section{The Secondary Positions}

Tonic reflexes bring about preparedness for action. Sherrington ${ }^{7}$ writes:

"One great function of the tonic reflexes is to maintain habitual attitudes and postures. They form, therefore, a nervous background of active equilibrium. It is of obvious advantage that this equilibrium should be easily upset, so that the animal may respond agilely to the passing events that break upon it as intercurrent stimuli ... 
"Of all reflexes, it is the tonic reflexes, e.g., of ordinary posture, that are in my experience the most easily interrupted by other reflexes."

The primary position of the eye is by tonic muscular action changed into a postural position or habitual attitude, in order to be ready for function. This secondary position could be called Phoria. It varies in response to consciousness, rest and function. Individuals vary in their phoria. The fullest readiness is orthophoria ; all other conditions of phoria are called heterophoria. Concerning orthophoria, Hofmann ${ }^{8}$ writes :

". Nach den Untersuchungen von Bielschowsky und anderen ist strenge Orthophorie nur eine seltene Ausnahme, gewissermassen ein schematischer Grenzfall."

Duke-Elder ${ }^{9}$ states :

"Orthophoria ... is extremely rare. Almost invariably a certain amount of imbalance or heterophoria exists."

The usual and normal condition therefore is heterophoria. Abnormality begins when heterophoria causes eyestrain.

As against the Primary Position, which is stable, passive, elastic equilibrium, Phoria is active equilibrium, "most easily interrupted by other reflexes," so that the organ "may respond agilely to passing events that break upon it as intercurrent stimuli."

In the Primary Position the visual axes have an angle, open towards the front. Phoria decreases that angle, eventually converting it into an angle open towards the back. Consequently the tonic action resulting in Phoria is regularly produced by the adductor muscles.

\section{The Significance of the Primary Position}

The words "muscle balance" and "muscle imbalance" are typical of the misconceived Primary Position.

My claim is that the extrinsic muscles of the eyes are tensors. They rotate the globus away from the Primary Position, and by inhibition allow that rotation to be reversed towards the Primary Position. The power for the reversed movement is supplied by the elasticity of that position, the regulation of time and step of the reversed movement is done by inhibition.

To illustrate this I quote Sherrington' $\mathbf{s}^{10}$ remarks and experiments. (The italics in this quotation are mine.)

"If III and IV cranial nerves of one side, e.g., left, have been severed, so that rectus externus remains the only unparalysed ocular muscle, appropriate excitation of the cortex cerebri produces conjugate movement of both eyes towards the opposite side, i.e., from left toward right, the left eye travelling however only so far as the median line. Inhibition of the 
tonus and of the active contraction of rectus externus can thus be elicited from the cortex. . . .

"E. H. Hering and myself made observations on limb movements ... For clearness of description let us suppose the left hemisphere excited, and the limb affected the right. The result of excitation of the appropriate focus in the cortex e.g., that presiding over extension of the elbow, is an immediate relaxation of the biceps, with active contraction of the triceps. ... As regards the condition of the biceps, the relaxation is usually so striking that merely to place the finger on it is enough to convince the observer that the muscle relaxes. . . .

". . . it may well be, indeed is in the highest degree likely, that in other fields of action one cortical element inhibits another cortical element.

"In 'willed' movements of the eyeballs of the monkey the same kind of co-ordination was revealed in some observations I obtained on this point. When the III and IV cranial nerves had been resected intra-cranially and the animals in ten days or so had recovered completely from the surgical interference, the eye movements were examined.

"In these animals if the gaze was attracted to an object, e.g., food, held level with the eyes and to the right of the median plane (left III and IV nerves cut) the left eye looked straight forward, the right eye looked to the right. If the object was then shifted more to the right or less to the right, the right eye followed it, moving as the object was moved, while the left eye remained motionless, looking straight forward all the time. But when the object was held to the left of the median plane, both eyes were directed upon it, apparently quite accurately. When the object was shifted farther and farther to the left both eyes followed it with a steady conjugate movement not detectably different from the normal. When the object was carried from the left-hand verge of the field back towards the median plane both eyes followed it as accurately as before. If the object was moved suddenly from the extreme left-hand edge of the field up to the median plane both eyes immediately and apparently equally quickly reverted to parallelism with that plane. Or, if the object were suddenly brought back from the left edge of the visual field to some point intermediate between that and the median plane both eyes at once shifted apparently equally to a correspondingly diminished deviation from the primary position. These actions must mean that in the left eye relaxation of rectus externus kept accurate time and step with contraction of the rectus externus of right eye. And the action of the left rectus externus gives presumably a faithful picture of a synchronous process going forward in the right rectus internus." 
From Sherrington's experiments it is clear that, as against what happens in a limb, the "antagonist" plays a passive rôle in most, if not all, ocular and binocular movements. This new conception drawn by me from Sherrington's classical experiments on inhibition should have far reaching effects on the theories of ocular, and especially binocular, motility.

Sherrington's experiments on inhibition offer a problem which can now be solved. It will have been noted that when the rectus internus is paralysed the globe can rotate, by cortical excitation, from the extreme external position to the median plane. What Sherrington means by "median plane" really is "anatomical-or primary-position." Of course this movement cannot be caused by inhibition. Inhibition can never be a motive force. I wish to point out that it is the elasticity of the primary position that does the work. The inhibition only regulates the effect of the traction continually exercised by the elasticity of the primary position. As, presumably, the law of inhibition applies equally to all extrinsic eye movement, it follows that any movement from the primary position towards the edge of the fixation field, and reversal of the movement from that edge towards the primary position, are both actuated by the same muscle. The movement away from the primary position is produced by contraction; the movement towards the primary position by inhibition of the muscle. The elasticity of the Primary Position is continually in action, whenever the eye is rotated out of it. During adduction, for instance, it is a counteracting power, which has to be overcome; during abduction from the internal edge of the fixation field up to the primary position it is the acting power whose time and step are regulated by inhibition of the adductor muscle.

For these reasons the term "muscle-balance" is based on a wrong conception. In extrinsic ocular movement there exists no balance between opposite muscular action. W' Wat there is of balance has to do with equilibrium between the traction of the primary position and extrinsic muscular action. Phoria is the result of this equilibrium. The equilibrium may be sufficient or insufficient for proper function. When it is sufficient, then the best possible posture, or habitual attitude, preparatory for binocular visual function is established.

\section{Summary}

As against the traditional arbitrary method of defining a "primary position" of the bi-unial eye, the real PRIMARY POSITION is recognised, viz.: the anatomical position of the organ. This position is the basis of kinetic binocular ophthalmology.

This anatomical position is one of divergence of the visual axes. 
The globes are firmly fixed in their orbital beds by connective tissue, ligaments and strands which all contain a strong quota of elastic elements. The result of this anatomical condition is: a stable equilibrium and an elasticity exercising permanent infuence on motions and positions of the organ.

Phoria is the name for all secondary positions. These are characterised by variation and instability.

From the stable, and elastic, equilibrium of the primary position the nature of ocular motility is considered.

A new conception of ocular motility is proposed.

The extrinsic muscles act as tensors between the primary position and the edge of the fixation field. They act by contraction in the direction away from the primary position. In the direction towards the primary position they act by inhibition only. Muscular contraction is never required for any movement towards the primary position.

The system of muscular antagonistic action which dominates movements of arms and legs is absent in extrinsic ocular movement. Its place is taken by a system of reciprocal action between extrinsic muscular power and the power of elasticity of the Primary Position.

The current expressions: "muscle-balance" and "muscleimbalance" are based on a wrong conception of anatomical and physiological facts, in so far as they relate to the eyes.

I desire here to acknowledge with gratitude the interest shown, and practical help given, in my work by Professor Raymond A. Dart, Sir Spencer Lister and Professor A. D. Stammers.

My thanks are also due to Mr. R. L. Caunter for his assistance in the investigations on the animals.

\section{REFERENCES}

1. Duke-Elder, W. Stewart.-Text Book of Ophthalmology, Vol. I, p. 584, 1932.

2. Ibid., p. 585.

3. Sherrington, C. S. - The Integrative Action of the Nervous System, pp. 279$280,1906$.

4. Duke-Elder.-Op. Cit., p. 579.

5. Worth, -Squint, p. 3, 1921.

6. Sutton, J. E., Jr.-Fascia of the Human Orbit. The Anatomical Record, Vol. XVIII, pp. 141-157, 1920.

7. Sherrington.-Op. Cit., p. 231.

8. Hofmann, F. B.-Die Lehre vom Raumsinn des Auges, p. 319, 1925.

9. Duke-Elder.-Op. Cit., Vol. I, p. 613.

10. Sherrington.-Op. Cit., pp. 280-286. 